\title{
Efektivitas Jaringan Komunikasi Masyarakat Terhadap Upaya Pencegahan Kejadian Stunting di Desa Cikulur Kabupaten Lebak Provinsi Banten
}

\author{
Retno Dyah Kusumastuti ${ }^{1}$, Muhammad Ikhsan Amar ${ }^{2}$ \\ ${ }^{1}$ Program Studi Ilmu Komunikasi, Universitas Pembangunan Nasional Veteran Jakarta \\ ${ }^{2}$ Program Studi Ilmu Gizi, Universitas Pembangunan Nasional Veteran Jakarta \\ Abstrak \\ Latar belakang: Prevalensi stunting di Provinsi Banten sebesar 33\%, yang terdiri dari 16,4\% sangat pendek dan \\ 16,6\% pendek. Kabupaten dengan prevalensi stunting tertinggi kedua di Banten adalah Kabupaten Lebak (38,1\%), \\ yakni sangat pendek 16,7\% dan pendek 21,4\%. Adanya fasilitas kesehatan dan jaringan komunikasi ini berfungsi \\ untuk mendeteksi dini malnutrisi pada suatu daerah. Peran ini dapat dikembangkan untuk pemanfaatan sarana- \\ prasarana di wilayah terkait untuk penyebaran informasi serta kemudahan akses dan peran aktif masyarakat, serta \\ kader posyandu. Hal tersebut dapat memengaruhi kesehatan ibu untuk secara rutin mengecek tumbuh kembang anak. \\ Keefektifan suatu kelompok mampu dipengaruhi oleh karateristik kelompok melalui jaringan komunikasi untuk \\ mengetahui pemuka opini (Opinion Leader) dan aktor dari jaringan serta keefektifan penyerapan informasi mengenai \\ stunting yang diintervensi oleh pemuka opini jaringan komunikasi, dan yang diintervensi dengan metode konseling, \\ pembinaan dan pemberdayaan. \\ Metode: Metode penelitian kualitatif deskriptif, dengan menggunakan pendekatan realis. Pendekatan realis yaitu \\ melihat jaringan dari perspektif responden (Aktor), dimana aktor yang akan menentukan sendiri posisisnya dalam \\ jaringan. \\ Hasil: Hasil penelitian yang menggunakan teknik wawancara mendalam dengan masyarakat menemukan terdapat \\ empat individu yang banyak dipilih oleh masyarakat. Keempat individu tersebut merupakan pemuka opini (Opinion \\ Leader) yang aktif dalam memberikan informasi terkait masalah kesehatan diantaranya masalah stunting, mampu \\ memberikan motivasi kepada anggota keluarga serta masyarakat. \\ Kesimpulan: Dengan melakukan komunikasi, pemuka opini (Opinion Leader) yang berisikan informasi serta \\ motivasi dalam setiap kegiatan dapat menumbuhkan upaya preventif yaitu pencegahan awal terjadinya masalah \\ stunting serta meningkatakan derajat kesehatan masyarakat. \\ Kata Kunci: Jaringan Komuniasi, Pemuka Opini (Opinion Leader) Stunting, kesehatan.

\section{Effectiveness of Communications Network Toward Prevention of Stunting in Cikulur Village, Lebak District, Banten Province}

\begin{abstract}
Background: Prevalence of stunting in Banten Province was 33\%, consisting of $16.4 \%$ very short and $16.6 \%$ short. The district with the second highest stunting prevalence in Banten is Lebak (38.1\%), which is very short $16.7 \%$ and short $21.4 \%$. Health facilities and communication networks serves to detect early malnutrition in an area which can be developed for the utilization of infrastructure in related areas for the dissemination as well as ease of access and the active role of the community, and posyandu cadres. This can affect maternal health to check the growth and development of children routinely. The effectiveness is influenced by group characteristics as communication network aimed at knowing opinion leaders (Opinion Leaders) and actors from the network as well as the effectiveness of information absorption on stunting that is intervened by the communication network opinion leaders, and which is intervened by the counseling method, coaching and empowerment.

Methods: Descriptive qualitative research methods, using a realist approach. The realist approach is to look at the network from the perspective of the respondent (Actor), where the actor will determine his own position in the network.

Result: The results of research using in-depth interviews with the community found that there were four individuals who were chosen by the community. The four individuals are opinion leaders (Opinion Leaders) who are active in providing information related to health issues including stunting issues, able to provide motivation to family members and the community.

Conclusion: By conducting communication, opinion leaders (Opinion Leaders) that contain information and motivation in each activity can foster preventive efforts, namely the early prevention of stunting problems and increasing the degree of public health.

Keywords: Communion Network, Stunting Opinion Leader, health.

Alamat Korespondensi :

Muhammad Ikhsan Amar

Universitas Pembangunan Nasional Veteran Jakarta,

Jl. RS. Fatmawati, Pondok Labu, Jakarta Selatan

Email: ikhsan90@upnvj.ac.id
\end{abstract}

Jurnal Ilmiah Kesehatan Masyarakat Vol. 12 Edisi 2, 2020 


\section{PENDAHULUAN}

Stunting atau yang dikenal dengan istilah pendek di tengah-tengah masyarakat merupakan masalah gizi kronis yang ditandai dengan nilai Z-Score <-2 SD. Stunting secara langsung disebabkan oleh ketidakcukupan asupan gizi serta pengaruh penyakit infeksi secara terus menerus saat 1000 hari pertama kehidupan sesorang. Kualitas bangsa di masa depan ditentukan oleh kualitas anak-anak saat ini. Upaya peningkatan kualitas sumber daya manusia harus dilakukan sejak dini, sistematis dan berkesinambungan. Tumbuh kembang anak yang optimal tergantung pada pemberian gizi dengan kualitas dan kuantitas yang baik serta benar. Dalam masa tumbuh kembang tersebut pemberian asupan makanan pada anak tidak selalu dapat dilaksanakan dengan sempurna. ${ }^{1}$

RISKESDAS 2013 melaporkan prevalensi balita stunting di Indonesia tercatat sebesar 37,2\%. Di Provinsi Banten, prevalensi stunting sebesar $33 \%$, yang terdiri dari $16,4 \%$ sangat pendek dan $16,6 \%$ pendek. Kabupaten dengan prevalensi stunting tertinggi kedua di Banten adalah Kabupaten Lebak $(38,1 \%)$, yakni sagat pendek $16,7 \%$ dan pendek $21,4 \%$. Gizi sangat penting untuk pertumbuhan, perkembangan, aktivitas, dan daya tahan tubuh, termasuk bagi anak-anak. Masa anak-anak merupakan salah satu periode yang paling kritis dalam menentukan kualitas sumber daya manusia. Pada siklus kehidupan manusia, masa anak merupakan masa yang relatif pendek tetapi sarat dengan proses pertumbuhan dan perkembangan sehingga menempati posisi yang penting. Asupan gizi balita menjadi salah satu faktor yang secara langsung dapat berkontribusi pada kejadian stunting, periode kehamilan hingga anak berusia dua tahun diyakini sebagai masa dimana gagal tumbuh kembang dapat dicegah (windows of opportunity). ${ }^{2}$

Hal ini sejalan dengan kajian The Lancet series 2016 bahwa pemberian ASI ekslusif dapat menurunkan mortalitas karena infeksi hingga $88 \%$ pada usia anak kurang dari 3 bulan. Asi ekslusif pada usia 6 bulan pertama dilanjutka hingga usia sampai 2 tahun serta pemberian makanan pendamping ASI (MP-ASI) yang cukup dan aman, berdasarka usia dari 6 sampai 23 bulan diharapkan mampu mengoptimalkan asupan gizi anak. ${ }^{2}$ Oleh karena itu, asupan gizi yang tidak optimal berpengaruh terhadap tumbuh kembang dan daya tahan tubuh anak, sehingga menyebabkan stunting yang sulit untuk diintervensu di masa depan. ${ }^{3}$ Baik buruknya pemenuhan gizi pada masa anak-anak dapat menentukan banyak aspek kehidupan di kemudian hari, seperti kesehatan, prestasi, intelektualitas, dan produktivitas pada masa remaja dan dewasa. Salah satu indikasi kejadian kurang gizi pada anak -anak adalah kejadian kependekan pada balita.

Penyakit infeksi pada balita juga berpengaruh langsung pada status gizi, penyakit infeksi dapat menyebabkan berat badan turun secara akut da berpengaruh pada status gizi balita. Balita dengan status gizi kurang akan menurunkan sistem imun dan menyebabkan balita mudah terkena penyakit infeksi ${ }^{13}$. Risiko jangka panjang dari penyakit infeksi adalah gangguang tumbuh kembang anak, tergantung dari tingkat keparahan. ${ }^{4}$ Menurut data RISKESDAS Indonesia, penyakit infeksi yang sering diderita oleh balita adalah Infeksi Saluran Pernapasan Atas (ISPA) hal ini didukung oleh data yang menunjukan bahwa prevalensi ISPA tercatat sebesar $24,8 \%$, mendekati prevalensi nasional $(25 \%) .{ }^{5}$ ISPA diperkirakan terjadi pada balita 3 sampai 6 kali pertahun ditandai dengan batuk pilek. ${ }^{6}$

Penelitian Mendez dan Adair menunjukkan anak yang stunted mempunyai pencapaian skor test kognitif yang lebih rendah dibandingkan anak dengan tinggi normal. Mereka juga mempunyai nilai yang lebih rendah pada pengujian bahasa dan matematika ${ }^{14}$. Penelitian Hizni et al. juga menemukan bahwa kejadian stunting pada anak usia di bawah lima tahun mempunyai hubungan yang nyata dengan perkembangan bahasanya. Kondisi ini sangat memprihatinkan, karena mengancam kualitas sumber daya manusia di masa yang akan datang apabila tidak ditangani secara serius dan dapat mengakibatkan bangsa Indonesia pada akhirnya mengalami lost generation ${ }^{15}$.

Menurut UNICEF stunting juga dipengaruhi oleh beberapa fakor tidak langsung seperti ketahanan pangan rumah tangga, pola asuh, serta fasilitas kesehatan. Kondisi ketahanan pangan rumah tangga merupakan faktor penting yang dapat mempengaruhi keadaan status gizi anggota keluarga terutama balita ${ }^{16}$. Kerawanan pangan pada keluarga dalam jangka panjang dapat berpengaruh terhadap konsumsi makanan dengan cara mengurangi kuantitas da kualitas makanan, sehingga terjadi ketidakcukupan zat gizi yang di butuhkan oleh tubuh dan berdampak pada tumbuh kembang balita. Pola asuh juga memberikan kontribusi yang sangat signifika terhadap kerjadian stunting, pola asuh yang di maksud melputi kurang optimalnya pemberian ASI Ekslusif, MP- ASI. 
Adanya fasilitas kesehatan dan jaringan komunikasi ini berfungsi untuk deteksi dini adanya malnutrisi pada suatu daerah peran ini dapat dikembagkan untuk pemanfaatan saranaprasarana di wilayah terkait untuk penyebaran informasi serta kemudahan akses dan peran aktif pejabat terkait, serta kader posyandu sehingga mempengaruhi kesertan ibu untuk secara rutin mengecek tumbuh kembang anak. ${ }^{7}$ Komunikasi di antara mereka lebih terbuka dibandingkan dengan orang yang lebih tua seperti pemuka agama, tokoh-tokoh masyarakat serta kaderkader kesehatan maupun orang tua, karena dengan penyebaran informasi atau teman kelompok dapat terjalin komunikasi yang erat, dimana mereka berfikir bawha ini merupakan tempat untuk memecahkan sebuah masalah yang mereka hadapi. Dalam penelitian Agustina \& Desmawati ditemukan lebih dari 50\% sumber informasi pengetahuan 1000 HPK yang di dapatkan dari teman dan media. ${ }^{8}$

Keefektifan suatu kelompok mampu dipengaruhi oleh karateristik kelompok, dimana salah satu karateristik kelompok adalah jaringan komunikasi. Evereett M. Rogers dalam Agustina, memberikan sebuah definisi bahwa jaringan komunikasi adalah suatu hubungan komunikasi pada suatu topik tertentu, dalam konteks peneltian ini 1000 HPK dalam keajadian stunting ${ }^{8}$. Dalam suatu jaringan komunikasi terdapat pemuka-pemuka opini (Opinion Leader) sebagai komunikator, dan anggota kelompok sebagai komunikan.

Penelitian ini bertujuan untuk mengetahui pemuka opini (Opinion Leader) dan aktor dari jaringan serta keefektifan penyerapan informasi mengenai stunting yang diintervensi oleh pemuka opini jaringan komunikasi, dan yang diintervensi dengan metode konseling. Secara rinci tujuan penelitian mengetahui pemuka opini jaringan, komunikasi untuk menjadi pemimpin dalam intervensi kejadian stunting. Kelompok A penelitia ini hendak mengatahui tingkat kejadian stunting responden sebelum dan sesudah intervensi tentang 1)Stunting (1000 HPK) 2)Pengetahuan tentang wanitas usia subur (WUS) 3)Pengetahuan tentang imunisasi serta kehamilan dan anak usia 0-23 bulan 4) Pemberian ASI da MP-ASI serta pemberia makanan tambahan (PMT) 5) Pengetahuan nutrisi pada bayi 0-24 bulan dan pengetahuan perkembagan anak usia 0-23 bulan. Adapun pengukura pengetahuan dilakukan dengan pengisian kuisioner HPK. Kriteria untuk menilai tingkat pengetahuan adalah tingkat pengetahuan kategori baik bila skor atau nilai 76-
$100 \%{ }^{9}$ Tingkat pengetahuan kategori cukup bila skor atau nilai $56-75 \%$ dan tingkat pengetahuan kategori kuranng bila skor $<50 \%$.

\section{METODE}

Metode penelitian deskriptif, menggunakan pendekatan realis. Pendekatan realis adalah dengan melihat jaringan dari sudut pandang responden (Aktor), dimana aktor akan menentukan posisinya dalam jaringan. ${ }^{10}$ Dalam studi ini, jaringan komunikasi berfokus pada aktor. Sampel dalam penelitian ini adalah masyarakat Cikulur yang termasuk dalam kategori remaja akhir pria dan wanita yang memenuhi syarat (WUS). 65 Responden, terdiri dari kelompok A dengan 32 responden dan kelompok B dengan 33 responden. Alasan memilih responden adalah karena usia remaja dan siap menjadi calon ibu, yaitu wanita usia subur (WUS). Selain materi yang dibahas sesuai dengan usia mereka, yang termasuk dalam kategori remaja akhir atau dikenal sebagai WUS (Wanita Usia Subur). Kriteria inklusi adalah remaja akhir dan orang dewasa, terdaftar dengan KTP atau informasi domisili selama 6 bulan yang tinggal di desa Cikulur. Sedangkan kriteria eksklusi adalah anak-anak yang belum mencapai usia remaja, lansia dan yang belum memiliki KTP di Desa Cikulur.

Pengumpulan data dilakukan pada Agustus-September 2019. Data pengetahuan tentang 1000 Hari Pertama Kehidupan dan data jaringan dikumpulkan dengan mendistribusikan kuesioner yang dilakukan oleh petugas (Enumerator), namun sebelum pengumpulan data responden diminta untuk bersiap mengisi lembar pernyataan untuk menjadi responden. Data dikumpulkan oleh tim peneliti. Teknik pengumpulan data jaringan komunikasi dengan mengidentifikasi responden (aktor), yaitu "menanyakan responden siapa teman terdekat Anda dan sering Anda diskusikan tentang kesehatan Anda" Responden diminta untuk menulis nama-nama empat teman/keluarga yang paling sering dihubungi pada kuesioner, kemudian kuesioner yang telah diisi dikumpulkan dan diedit. Setelah diedit, data diproses dengan perangkat lunak analisis jejaring sosial. Dari analisis jaringan, kami mendapatkan diagram sosiometrik, yang menunjukkan hubungan antara satu aktor dan aktor lainnya. Diagram sosiometrik dari penelitian ini menggunakan bantuan perangkat lunak UCINET. Dari analisis diagram sosiometrik, diperoleh pendapat pemimpin (Opinion Leader) dan anggota jaringan. Opinion Leader (Opinion 
Leader) akan menjadi pemimpin dalam jaringan yang sebelumnya telah diberikan pelatihan tentang penanganan stunting dan 100 Hari Pertama kehidupan oleh tim peneliti. Setelah itu, pemimpin opini (Opinion Leader) dapat mengembangkan materi sebelum mengintervensi. Kelompok A diintervensi oleh pemimpin opini (Opinion Leader) dengan metode diskusi, dan kelompok B diintervensi oleh tim peneliti dengan metode ceramah.

\section{HASIL}

Hasil analisis jaringan komunikasi kelompok dapat dilihat pada diagram sosiometrik di bawah ini. Dari diagram ini, kita mendapatkan arah hubungan antara satu aktor dan aktor lainnya. Beberapa aktor diposisikan sebagai subjek (Pengirim pesan) dan ada objek (Penerima pesan).

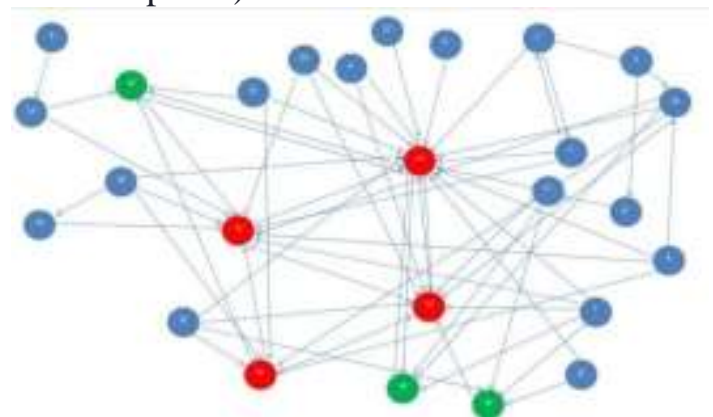

\section{Graphs of Sociometry Communication Networks}

Hasil penelitian melalui analisis diagram sosiometrik menunjukkan bahwa dari 32 responden kelompok, aktor ditemukan sebagai subjek (pengirim pesan) dan juga objek (penerima pesan). Sebagai pengirim pesan dan penerima pesan adalah "A", "M", "Y", dan "R". sementara yang lain diposisikan sebagai penerima pesaN (Obyek). Aktor yang diposisikan sebagai subjek dan objek, dalam penelitian ini menjadi pemimpin opini. Pemimpin opini menjadi pemimpin dalam diskusi, dalam kelompok di masyarakat untuk mengatasi masalah stunting. Jadi pemimpin opini dalam penelitian ini berjumlah lima orang. Kelima pemimpin opini memimpin diskusi dan dapat memberikan intervensi kepada masyarakat dalam mengurangi kejadian stunting (Objek). Dari uraian kondisi di atas, dapat disimpulkan bahwa aktor komunikasi memiliki kedekatan dan komunikasi yang mereka lakukan juga dapat dikatakan sangat intens, berdasarkan hasil pengamatan mendalam dan wawancara, aktor komunikasi sangat berpengaruh. komunikan di komunitas. Sehingga terbentuklah klik antara empat anggota komunitas.

\section{PEMBAHASAN}

Jaringan komunikasi dapat diselidiki melalui tiga tingkatan, yaitu individu, klik, dan sistem. Dari hubungan yang dibentuk oleh empat individu di atas, yaitu "A", "N", "M", "Y", dan "R". Kemudian tingkat jaringan komunikasi dapat dianalisis sebagai berikut.

\section{Tingkat Individu}

Apa yang perlu dipertimbangkan pada tingkat ini dalam jaringan komunikasi adalah bagaimana hubungan individu dengan individu lain dalam suatu sistem terkait dengan proses memilih dan dipilih sebagai sumber informasi. ${ }^{11}$ Dilihat dari sosiogram individu "A" (16) banyak yang dipilih dan memilih orang lain. Jadi dapat disimpulkan bahwa inisial "A" adalah individu yang telah dipilih dan memiliki peran penting dalam sebuah komunitas dan dapat memberikan informasi dan peran yang sangat penting dalam penyampaian informasi tentang kesehatan, terutama yang berkaitan dengan stunting. Penelitian ini hanya menghasilkan satu klik, tetapi cukup alami di komunitas. Namun, kondisional di tengah-tengah masyarakat responden yang memiliki kedekatan emosional dengan masyarakat sehingga lebih banyak informasi tersebar di antara individu-individu di lingkungan.

\section{Level Sistem}

Jaringan komunikasi pada tingkat sistem dapat diuji dari jumlah hubungan anggota yang melintasi batas sistem dan dibagi dengan jumlah hubungan yang mungkin terjadi. Namun dalam penelitian ini, para peneliti tidak menemukan hubungan antara dengan komunitas lain yang secara langsung berkomunikasi dan berbagi paparan informasi, karena tidak ada derajat keterbukaan antara individu di dalam dan di luar komunitas. Maka, dapat disimpulkan bahwa analisis pada tingkat sistem tidak diperlukan.

Analisis univariat dilakukan untuk menggambarkan masing-masing sub-bagian dari variabel mengenai stunting. Deskripsi pengetahuan responden tentang stunting sebelum dan sesudah intervensi. Hasil penelitian menemukan bahwa pengetahuan kelompok A, sebelum diberi pengetahuan pra-test dan posttest stunting, menunjukkan 68,7\% dalam kategori rendah, sedangkan kelompok B memiliki kategori rendah $72,7 \%$. Dapat disimpulkan bahwa pengetahuan kelompok A sebelum diberi pre-test dan post-test lebih baik daripada di kelompok B. Setelah diberi pre-test dan post-test 
ada peningkatan pengetahuan, kelompok A di kategori baik meningkat menjadi 90,6\% sementara kelompok B meningkat menjadi $81,8 \%$.

Pengetahuan tentang stunting sangat penting bagi masyarakat terutama bagi wanita usia subur, sebagai dasar untuk membentuk perilaku sehat dalam kehamilan, dan sebagai langkah awal dalam mempersiapkan kesehatannya untuk menjadi calon ibu yang akan mencetak generasi masa depan yang berkualitas. Pengetahuan stunting dan 1000HPK adalah tahap yang sangat penting untuk diketahui oleh wanita usia subur (WUS) untuk menghindari masalah kesehatan pada ibu, dan janin yang gagal pertumbuhan fisik, penurunan tingkat kecerdasan anak, penurunan kekebalan. ${ }^{12}$ Penelitian ini sejalan dengan Agustina pada tahun 2016 yang menunjukkan bahwa sebagian besar wanita muda mengetahui kurangnya pengetahuan tentang stunting dan 1000HPK. ${ }^{8}$

\section{KESIMPULAN}

Hasil penelitian dari diagram sosiometrik menemukan empat pemimpin opini, mereka sebagai pengirim dan penerima pesan, keempat pemimpin opini tersebut adalah pemimpin diskusi. Deskripsi pengetahuan 1000 HPK dalam hal ini kekhususan terkait dengan masalah stunting sebelum diberikan intervensi (Pre-Test), tentang istilah $1000 \mathrm{HPK}$, pengetahuan stunting. Setelah intervensi (Pra-Test), dan lebih banyak pengamatan mendalam terkait dengan masalah 1000 HPK dan pengerdilan dalam penelitian ini, ada peningkatan ke kategori yang baik. Namun, nilai pengetahuan kelompok A yang diberikan oleh pemimpin opini dalam jaringan komunikasi dengan metode diskusi lebih tinggi dalam penyerapan daripada nilai kelompok $\mathrm{B}$ yang diberikan oleh metode ceramah. Jadi administrasi 1000 intervensi HPK (Stunting) cenderung lebih baik melalui pemimpin opini jaringan komunikasi.

\section{DAFTAR PUSTAKA}

1. W J. Perilaku makan anak sekolah Direktorat Bina Gizi Kementerian KesehatanRepublik Indonesia [Internet]. 2018 [cited 2018 Jul 22]. Available from: http://gizi.depkes.go.id/makalah/downlo a d/perilaku makan anak sekolah.pdf

2. UNICEF. United Nations and Children's Fund.Infant and Young Child Feeding. New York; 2011.
3. WHO. WHA Golobal Nutrition Targets 2025 : Anaemia Policy Brief. 2014.

4. WHO. World Health Organization LGBT Report: Globalhealth.gov [Internet]. 2013 [cited 2018 Jul 26]. Available from: http://www.globalhealth.gov/globalhealth topics/lgbt/lgbt_report.html

5. RI K. Riskesdas dalam Angka Provinsi DKI Jakarta 2013. Jakarta: Lembaga Penertbitan Badan Penelitian dan Pengembangan Kesehatan Kemenkes RI; 2013.

6. Farmasi PB dan. Puslitbang Biomedis dan Farmasi. Jakarta; 2009.

7. Marifat. Analisis Hubungan Pemanfaatan Pelayanan Kesehatan dengan Status Gizi Anak Balita. Bogor. 2010.

8. Agustina. Efektifitas Jaringan Komunikasi Remaja Akhir Putri Sebagai Intervensi Peningkatan Pengetahuan 1000-HPK. Universitas Pembangunan Nasional Veteran Jakarta; 2016.

9. Nursalam. Konsep dan Penerapan Metodelogi Penelitian Ilmu Keperawatan. Jakarta: Salemba Medika; 2008.

10. Eryanto. Analisis Jaringan Komunikasi. Jakarta: Prenada Media; 2014.

11. Rogers EM. Diffusion of Innovations. London: The Free Press; 1983.

12. Saifuddin AB. Ilmu Kebidanan. Jakarta: Bina Pustaka Sarwono Prawhardjo; 2010.

13. Wellina, W. F., Kartasurya, M. I., \& Rahfiludin, M. Z. (2016). Faktor risiko stunting pada anak umur 12-24 bulan. Jurnal Gizi Indonesia (The Indonesian Journal of Nutrition), 5(1), 55-61.

14. Mendez, M. A., \& Adair, L. S. (1999). Severity and timing of stunting in the first two years of life affect performance on cognitive tests in late childhood. The Journal of nutrition, 129(8), 1555-1562.

15. Hizni, A., \& Julia, M. (2009). Hubungan status stunted dengan perkembangan balita di wilayah pesisir pantai utara Kecamatan Lemahwungkuk Kota Cirebon. Doctoral dissertation. Yogyakarta: Universitas Gadjah Mada.

16. Kandeepan, K., Arasaratnam, V., \& Balakumar, S. (2016). Nutritional status and food insecurity among the children in Northern Sri Lanka. 